\title{
THE INFLUENCE OF SOCIAL MEDIA ADVERTISING ON PURCHASING DECISIONS AT STARTUP COMPANIES
}

\author{
Dany Perdana Sitompul ${ }^{\star 1}$, Ferawati ${ }^{2}$ \\ Politeknik Wilmar Bisnis Indonesia*12 \\ dany.sitompul@wbi.ac.id ${ }^{* 1}, \underline{\text { ferawati@wbi.ac.id }{ }^{2}}$
}

\begin{abstract}
The era of globalization, better known as the Industrial Revolution, Era 4.0, makes all sectors change. We are starting to see massive efficiency where output becomes one of the targeted indicators. The maximum disclosure of information with almost free access can be a huge opportunity for a company to startups compete on a wide scale. Marketing is an activity that should always be included, from everything carried out by large companies to Startups or SMEs. In this new era, marketing is generally executed out in two ways, traditional and digital. We also know that social media is an individual quite widely used for personal and business purposes. And the use of this new digital trend in marketing has also greatly increased, becoming the media used by almost every company or startup in carrying out its marketing campaigns. The specific purpose of this research is to understand the true impact of social media marketing and how effective this marketing is in the era of industrial revolution 4.0. This research was conducted by distributing questionnaires to Startups in Medan, North Sumatera The testing is done empirically and consumers tend to lean on great communication and indication of a strong collaboration.
\end{abstract}

Keywords: Marketing; Social Media; Startup Businesses

\section{INTRODUCTION}

The era of digitalization is a very common subject in our society. If we see largescale companies' scope up to startups, they generally do marketing in two ways, traditionally and digitally. In 2018, Indonesia's population reached more than 260 million people. Where, based on data obtained from Hootsuite, 132.7 million Indonesians use the internet. Of the 132.7 million, 130 million people in Indonesia have social media accounts. The data from above makes the potential of using a company's e-marketing in running its business marketing campaign very intriguing. The use of digital marketing, in this form, social media, is very practical and can reach all the desired directions without high costs (Prasetya \& So, 2014). However, in this research, does making a marketing campaign based on social media will have a positive impact on a business's revenue? Does the increase in the number of followers lead to increased income? Based on the background of the problem, this research is necessary. The specific purpose of this research is to understand the true impact of social media marketing and how effective this marketing is in the era of industrial revolution 4.0. It is very easy to use social media, and anyone can use and access it anywhere and anytime. However, without the purpose and results of analyzing the correct data, a social media marketing campaign will be in vain, so this urgency is the background for researchers to conduct this research.

Kotler and Keller (2016) state that marketing is a process by which companies create value for customers and build strong customer relationships to get value from customers in return. Marketing communication is a key element that effectively provides the right information to customers about the company or startup's products or services. The form of communication carried out by companies also varies greatly, making a product or service more attractive. Marketing communication is crucial because it becomes a medium in which companies try to convey information, invite and remind consumers directly or indirectly about the brand or product, or service sold, as stated 
(Kotler, 2014). Of the various media that can be used for marketing by a company or startup, e-marketing is the media that is the most frequently used in the era of the industrial revolution 4.0 (Armesh et al., 2010). This online activity is useful for increasing customer awareness, directly and even indirectly, increasing impressions and expected to get sales of products or services as stated by (Kotler et al., 2017). It is well known that many Indonesians use the internet and social media, a figure that reaches more than $50 \%$ of Indonesia's total population.

Social media has also become a trend in communication which is very popular among Indonesians. The Ministry of Trade of the Republic of Indonesia, through its public relations center team, said that social media is an online media, where users through internet-based applications can share, participate and create content through blogs, wikis, forums, social networks, and virtual space supported by increasingly sophisticated multimedia technology. Social media also varies greatly from personal use to socializing to conveying information from different perspectives (Kotler et al., 2017).

Another interesting thing is the high consumption of the Indonesian population, both offline and online. We can see that customers who choose, decide, or buy a product and service are consumer behavior. We can learn why the customer decided to buy a product or service wherefrom looking at consumer behavior. A customer's decision to buy comes from a matter that involves a choice between two or more alternative actions or behaviors. Peter \& Olson (2012) also said five roles occur in purchasing decisions, namely;

Initiator, the person who first suggests buying a particular product or service. Influencer, a person whose views or advice give weight to the final decision. Decision maker, the person who determines part or all of the purchasing decision, whether to buy, what to buy, when to buy, how to buy, and where to buy. Buyer (Buyer), the person who made a real purchase. Users, people who consume or use products/services. The above activities are carried out to achieve a goal or target desired by a company or startup. Social media for marketing activities changes the way small to large companies deal with and convey information about their products or services. In the past, using traditional methods, it took a long time to convey information and did not necessarily arrive at the desired or appropriate prospect. With one press of a certain button on the device used with social media, a business or company can convey information about its products and services in seconds. What makes social media the most in marketing is the excellence in conveying information to the desired customer criteria. There is no time limit or distance. Plus, the costs incurred in marketing through social media are smaller than traditional marketing at the same distance and time. Like traditional marketing, it does not mean a concrete guarantee that using social media marketing will directly make customers buy. Of course, there are processes or stages that customers go through in determining the decision to purchase a product or service, as seen below Figure 1: 


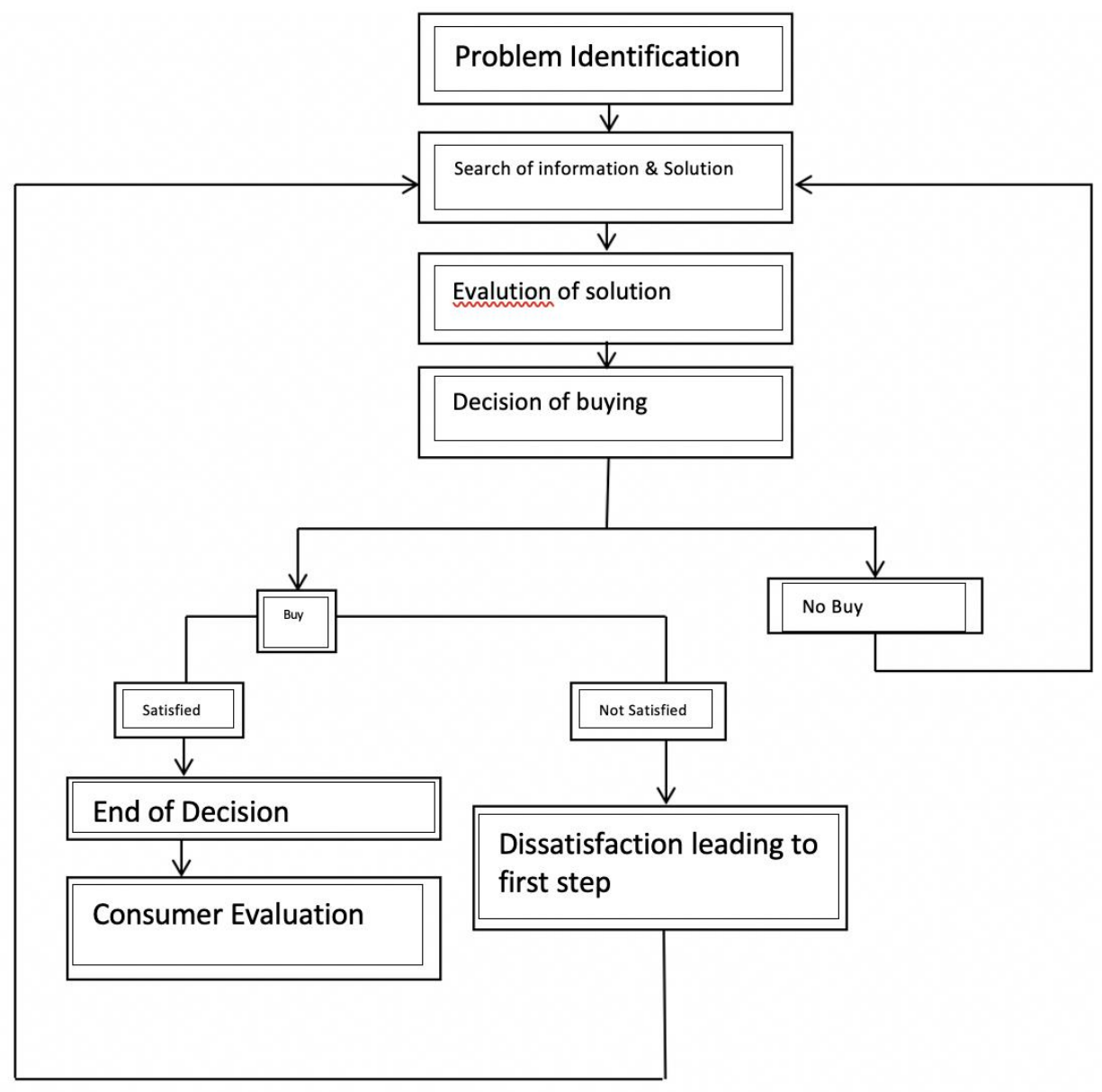

Figure 1. Consumer Purchase Decision Making Process Source:(Djovanka, 2017)

\section{METHODS}

The research method that will use conducting this research is to use a survey. The head researcher and members will carry out the research design in the first month to form the right concepts and schemes in this research. Researchers will use a questionnaire as a data collection tool. This is to get a clearer picture of the cause and effect of all the variables studied. The population studied was consumers from Start-Ups in Medan. The second month of this research is to collect data on Startups in Medan and how many of them use social media marketing. The achievement indicator is getting 20 Startup businesses that use social media marketing.

Next, the following month, data collection is accomplished using the Simple Random Sampling Method; researchers will take data from consumers who make purchases at a startup and see whether the purchase decision comes from marketing carried out by a startup through social media. The target indicators for achievement are 200 consumers from various Startup businesses who use social media to make product or service purchase decisions. During the data collection process, there will be documentation of every activity starting from collecting journals, archives, and other document sources relevant to this research. Sources of data collected are divided into primary \& secondary data. Assuming that the development of Startups in Medan has 
been quite significant lately, the data collection will be carried out by the proposing members and other members for a total of three (3) months. The data processing process will last for two (2) months by the head researcher, where the output is a discussion draft of the research results, which will be an indicator of achievement at this stage.

Data processing will use several classical tests, starting from the normality test, multicollinearity test, autocorrelation test, and validity and reliability testing. In the end, the research report on the final results will be carried out by the head researcher and research members, which will last for three (3) months, with the indicator of the results being a research document that includes the analysis results and conclusions of the research conducted. The total study total was nine (9) months.

\section{RESULTS AND DISCUSSION}

Table 1. Respondents by Age

\begin{tabular}{ccc}
\hline Age & Frequency & Percentage \\
\hline $16-19$ Years & 47 & $24 \%$ \\
$20-29$ Years & 89 & $45 \%$ \\
$30-40$ Years & 62 & $31 \%$ \\
$41-50$ Years & 1 & $1 \%$ \\
$>50$ Years & 1 & $1 \%$ \\
Total & 200 & $100 \%$ \\
\hline Source: Data processed by the author $(2020)$
\end{tabular}

Respondents used in this study were 200 people. In table 1, we can see most respondents who purchase as a result of social media advertising are varied mostly from age 30-40 years old, 20-29 years old, and 16-19 years old. Most consumptions are from consumers by the age of 20-29 years of age, and this data is also by what Hootsuite (Figure 2) describes where age from 18-34 years old are the main correspondents of social media.

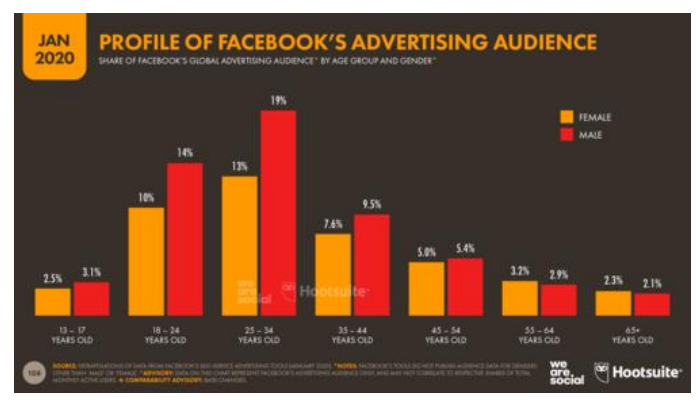

Figure 2. Advertising Audience 2020 Source: (We Are Social \& Hootsuite, 2020)

Table 2. Respondents by Sex

\begin{tabular}{ccc}
\hline Sex & Frequency & Percentage \\
\hline Male & 56 & $39 \%$ \\
Female & 144 & $72 \%$ \\
Total & \multicolumn{2}{c}{$\mathbf{2 0 0}$} \\
Source: Data processed by the author (2020)
\end{tabular}


We could also see that according to sex, $72 \%$ of consumers are female, and $39 \%$ are male (Tabel 2). This identifies that females dominate the consumption of products and services.

Table 3. Coefficients ${ }^{a}$

\begin{tabular}{ccccccccc}
\hline Model & & $\begin{array}{c}\text { Unstandardized } \\
\text { Coef. }\end{array}$ & S.Er & Beta & t & Sig & Tolerance & VIF \\
\hline 1 & X1 & 1.982 & .499 & .110 & 1.966 & .051 & .365 & 2.736 \\
X2 & 1.123 & .665 & .112 & 1.185 & .853 & .302 & 3.315 \\
X3 & 1.489 & .557 & .155 & 2.674 & .008 & .284 & 3.518 \\
X4 & 2.786 & .509 & .278 & 5.473 & .000 & .370 & 2.700 \\
X5 & 1.584 & .560 & .176 & 2.829 & .005 & .245 & 4.074 \\
X6 & 2.116 & .421 & .266 & 5.022 & .000 & .340 & 2.942 \\
& X7 & 1.706 & .533 & .182 & 1.323 & .187 & .250 & 4.001 \\
X8 & 2.647 & .568 & .277 & 4.664 & .000 & .272 & 3.683 \\
& X9 & 1.641 & .476 & .165 & 1.346 & .180 & .410 & 2.437 \\
X10 & 1.576 & .448 & .165 & 1.287 & .200 & .375 & 2.665 \\
\hline \multicolumn{7}{c}{ Source: Data processed by the author (2020) } \\
\end{tabular}

Table 4. Model Summaryb

\begin{tabular}{llllll}
\hline Model & $\mathrm{R}$ & $\mathrm{R}$ Square & Adj R Square & Std Err & Durbin-watson \\
\hline 1 & .905 & .820 & .810 & 3.340 & 1.895 \\
\hline \multicolumn{5}{c}{ Source: Data processed by the author (2020) }
\end{tabular}

As we run the data through SPSS, the data processing includes the following classical tests. The author will start from the normality test, where the results show the data spread along the diagonal line, which highlights it is distributed normally. When testing the multicollinearity test, the data tested indicates no multicollinearity signs as all data shows a larger value of tolerance more than 0,1 and a smaller VIF value than 10 , as seen in Table 3. The autocorrelation test runs on SPSS 25, seen in Table 4, indicate the Durbin-Watson value on this test is 1.895 , meaning that the data run does not indicate autocorrelation.

A partial t-test is run so we can indicate which independent variables show effects on the dependent variables (Ghozali, 2013). In this research, seen in Table 3, it is found that Communication and Collaboration are the variables that effects Buying Decision from Social Media Advertising of Startup companies in Medan.

\section{CONCLUSION}

As shown by the data above, the authors conclude that the variables that affect buying decisions by social media advertisement are great communication that implicates what is being sold. And a strong indication of collaboration between businesses and consumers. These two variables are the most important among other variables when using social media advertising in marketing Startup Businesses in Medan. Consumers tend to lean on great communication and indication of a strong collaboration. Among consumers that buy are mostly women by the age of 20 to 40 years old. And by that age group, $76 \%$ use social media as a tool of information and buying decision making.

Startup Businesses in Medan should strongly encourage using Social Media Advertisements in their marketing campaign and focus their content on communication and collaboration. This is highly recommended if your consumer age group is around 20 to 40 years old. 


\section{REFERENCES}

Armesh, H., Salarzehi, H., Salarzehi, H., Yaghoobi, N. M., Yaghoobi, N. M., Heydari, A., ... Nikbin, D. (2010). Impact of Online/Internet Marketing on Computer Industry in Malaysia in Enhancing Consumer Experience. International Journal of Marketing Studies, 2(2). https://doi.org/10.5539/ijms.v2n2p75

Djovanka, T. A. (2017). Pengaruh Social Media Advertising terhadap Keputusan Pembelian di A2 Kafe Medan.

Ghozali, I. (2013). Ghozali, Imam (2013). Aplikasi Analisis Multivariate Dengan Program IBM SPSS 21 Update PLS Regresi. Semarang: Badan Penerbit Universitas Diponegoro.

Kotler, P. (2014). Principles of Marketing (15th ed.). Harlow : Pearson Education.

Kotler, P., Armstrong, G., Ang, S. H., Tan, C. T., Yau, O. H.-M., \& Leong, S. M. (2017). Principles of Marketing ( An Asian Perspective ). In Pearson, 4.

Kotler, P., \& Keller, K. L. (2016). Marketing Management Global Edition (Vol. 15E). https://doi.org/10.1080/08911760903022556

Peter, P. J., \& Olson, J. C. (2012). Consumer Behavior Marketing.

Prasetya, F. N., \& So, I. G. (2014). Pengaruh E-Marketing dan E-Crm Terhadap ELoyalty Website Usaha Komunikasi Pemasaran. Binus Business Review, 5(1). https://doi.org/10.21512/bbr.v5i1.1191

We Are Social \& Hootsuite. (2020). Indonesia Digital report 2020. Global Digital Insights, 43. 